\title{
The volatilome - investigation of volatile organic metabolites (VOM) as potential tumor markers in patients with head and neck squamous cell carcinoma (HNSCC)
}

Philipp Opitz ${ }^{1 *}$ (D) and Olf Herbarth ${ }^{2}$

\begin{abstract}
Background: Different organisms such as bacteria, molds and humans produce and release a relative unknown class of metabolites which are responsible for the individual olfactory pattern. These volatile organic metabolites (VOM) represent a kind of biosignature that reflects the sum of all multifactorial influences, including genetics, environmental factors, nutritional and disease status. As a result of pathological processes the individual body odor can be influenced by newly produced or altered compositions of the VOM. Until now, human VOM have been detected in various body media, such as on the skin, in the exhaled air as well as in body fluids such as saliva, mother's milk, sweat, blood and urine.
\end{abstract}

Methods: In this retrospective case-control study urinary VOM of 53 therapy-naive patients with head and neck squamous cell carcinoma (HNSCC) and 82 healthy controls were semi-quantified by headspace solid-phase micro extraction (SPME) gas chromatography (GC) mass spectrometry (MS). At first, the procedure was optimized in respect to the extraction parameters. By using Student's $t$-test significant differences in the VOM pattern with the corresponding $p$-values were obtained. For multivariate metabolite pattern recognition the hierarchical cluster analysis by Ward was applied, followed by the supervised partial least squares-discriminant analysis (PLS-DA).

Results: In total 81 VOMs could identified in the urine samples of all study participants, of which 25 were significantly increased and of which were 10 significantly reduced in HNSCC-patients compared to the controls. In addition, the multivariate statistics confirmed that on the basis of the renal excreted pattern of the volatile metabolites a high discrimination can be carried out between patients with a tumor in the head and neck region and controls. The substance group of the saturated, unbranched aldehydes makes a substantial contribution in this context.

Conclusions: The systematic pattern analysis of urinary VOMs appears to have potential clinical application as a diagnostic tool for cancer, especially HNSCC.

Keywords: Tumor marker, Urinary metabolites, Volatile organic metabolites (VOM), Non-invasive diagnostics, Head and neck squamous cell carcinoma (HNSCC), Solid-phase micro extraction (SPME)

\footnotetext{
* Correspondence: Philipp.Opitz@medizin.uni-leipzig.de

'Institute of Hygiene, Hospital Hygiene and Environmental Medicine,

University Hospital Leipzig, Johannisallee 34, 04103 Leipzig, Germany

Full list of author information is available at the end of the article
}

(c) The Author(s). 2018 Open Access This article is distributed under the terms of the Creative Commons Attribution 4.0 International License (http://creativecommons.org/licenses/by/4.0/), which permits unrestricted use, distribution, and reproduction in any medium, provided you give appropriate credit to the original author(s) and the source, provide a link to the Creative Commons license, and indicate if changes were made. The Creative Commons Public Domain Dedication waiver (http://creativecommons.org/publicdomain/zero/1.0/) applies to the data made available in this article, unless otherwise stated. 


\section{Background}

According to the World Health Organization (WHO) volatile organic compounds (VOC) are outlined as carbonaceous substances with a boiling point range between 50 and $260{ }^{\circ} \mathrm{C}$. These compounds result from natural but also from anthropogenic origin [38] and they are ubiquitous, which means that they are found both indoors and outdoors. However, the pollution indoors is given a special importance [39]. The entry sources are versatile: besides building materials, furnishings, floor coverings, paints and lacquers, as well as activities such as smoking, cooking and hobbies play a decisive role [15, 24].

In addition to pollutants from the indoor air, hundreds to thousands of VOC are produced by the human organism and released to the environment. On the one hand, they are responsible for the typically individual body odor and on the other hand they reflect the metabolic conditions of the respective individual. Therefore, a further term has been established: "volatile organic metabolites" (VOM) [34, 35]. These volatile metabolites can be detected in various media of the body, such as on the skin and in the exhaled air, as well as in body fluids such as saliva, mother's milk, sweat, blood and urine [1, 18]. VOM represent a kind of biosignature which depicts the sum of the multifactorial influences to an individual, e.g. genetics, environmental factors, nutritional status and disease status [2]. As a result of pathological processes the individual body odor can be influenced by newly produced or altered compositions of the VOM, including infections or endogenously caused metabolic disorders [14]. In this case, the VOMs are not bound to be formed exclusively endogenously in the organism, they can also occur from exogenous sources and thus they reflect the exposome. They can be derived from food, from inhaled pollutants from indoor air and from stimulants such as tobacco smoke and alcohol consumption. In addition, growing microorganisms produce a series of volatile secondary metabolites, so-called microbial volatile organic compounds (MVOC), which are again metabolized by the colonized host or interact with the metabolites of the host and generate therefrom new VOCs. This leads, for example, to a foul smell of exhaled air in respiratory infections [6].

For this reason, it is of great interest to derive disease-specific VOMs for the medical diagnosis of different diseases, which appear as olfactory biomarkers. Conclusions about certain VOMs can be drawn by understanding the pathophysiological mechanisms, which provide insights for appropriate therapeutic treatment approaches. These markers are formed by diseased or healthy cells in the organism in response to the disease [37]. In reference to tumor diseases a change in the microbial colonization of the organism is assumed, which modulates the pattern of the VOMs. A number of studies have shown that the VOMs can be used to discriminate between different diseases $[5,23,36]$. In recent years, cancer-specific VOMs are increasingly being discussed their role as tumor markers [11, 22, 26, 27, 32].

Considering that head and neck cancers represent the sixth most common cancer worldwide with more than 550.000 cases and 380.000 deaths per year the search towards appropriate tumor markers for an early and reliable diagnostics must be expedited vehemently. The risk factors for development of head and neck squamous cell carcinomas (HNSCC) include smoking, excessive alcohol consumption, and infection with human papillomavirus or Epstein-Barr virus. Amongst other things, high expectations are being placed on the elucidation of the human metabolome, since the metabolites pass through all complex enzymatic pathways and thus are excreted as end products of the metabolism.

\section{Methods}

Patients and study population / collection of urine samples For the extraction of the VOMs from the urine material a retrospective case-control study including total $n=53$ patients with pathohistological confirmed HNSCC and $n=82$ healthy volunteers served as a basis. Patients were recruited at the head and neck (ENT) clinic of the University Hospital Leipzig between 03/2009 and 09/2011; details see Table 1 . The localization of the primary tumors comprised larynx, hypopharynx, oropharynx, and oral cavity. In all cases the urine sample was obtained before starting the curative therapy. Healthy controls were matched according to the criteria depict age, sex and the predominant lifestyle factors in HNSCC, i.e. tobacco smoking and alcohol consumption. It has to be pointed out that the matching regarding life style factors was not possible in detail for each case. The participants of the control group have been obtained from different studies: LIFE (Leipziger Forschungszentrum für Zivilisationserkrankungen - Leipzig research center for diseases of civilization), recruitment at the ENT-Clinic (patients without cancer, inflammatory diseases or pregnancy), and an internal study for creation of reference values. All urine samples were taken after obtaining the patients written informed consents as approved by the local institutional review board (votes of the ethics committee of the Medical Faculty of the University Leipzig (No. 201-10-12,072,010 \& No. 202-10-12,072,010)).

The urines were filtered immediately using a $0.2 \mu \mathrm{m}$ membrane cellulose acetate filter (Sartorius) to remove any sediment potentially containing epithelial cell, erythrocytes, bacteria and proteins which disturb the further analysis. The filtered urine samples were stored at minus $20{ }^{\circ} \mathrm{C}$ no longer than 8 weeks until processed.

\section{Reagents}

Helium N50 and nitrogen N50 (both purity 99.999\%) were purchased from AirLiquid (Düsseldorf, Germany). 
Table 1 Clinical characteristics of the HNSCC group (UICC staging system $=$ Union internationale centre le cancer)

\begin{tabular}{lll}
\hline Mean age & 61.0 & $(\%)$ \\
\hline Sex & $n$ & $(81.1 \%)$ \\
Male & 43 & $(18.9 \%)$ \\
Female & 10 & \\
UICC stage & & $(7.5 \%)$ \\
I & 4 & $(11.3 \%)$ \\
II & 6 & $(18.9 \%)$ \\
III & 10 & $(56.6 \%)$ \\
IVA & 30 & $(5.7 \%)$ \\
IVB & 3 & $(0 \%)$ \\
IVC & - & \\
Localisation & & $(52.8 \%)$ \\
Oropharynx & 28 & $(18.9 \%)$ \\
Hypopharynx & 10 & $(18.9 \%)$ \\
Larynx & 10 & $(9.4 \%)$ \\
Oral cavity & 5 & $(77.4 \%)$ \\
Tobacco consumption & $14.6 \%)$ \\
Yes & & \\
No & & \\
Alcohol consumption & & $(79.2 \%)$ \\
Yes & 42 & $(20.8 \%)$ \\
No & 11 & \\
\hline
\end{tabular}

Deionized water was acquired from a Milli O plus purification system (Merck Millipore, Bedford, MA, USA). 99.99\% Suprapur sodium chloride $(\mathrm{NaCl})$ and $25 \%$ pure hydrochloric acid $(\mathrm{HCl})$ were received from Merck (Darmstadt, Germany) respectively AppliChem (Darmstadt, Germany).

\section{Headspace solid-phase micro extraction (SPME)}

The extraction of the VOM was done by the fast and solvent-free method of solid-phase microextraction (SPME). This method involves the sampling, extraction and concentration of the analytes in a single step and was first described by C. Arthur and J. Pawliszyn [3]. The extraction can be carried out either directly from the urine sample or in the headspace. In this case, the enrichment in the headspace was preferred, since this handling is both the more gentle application for the SPME fiber and minimizes the aqueous residues reaching for the gas chromatograph (GC) column. A Carboxen / PDMS coated fiber from Supelco (Bellefonte, PA, USA) was applied for the adsorption of the VOM. Therefore, the following sentences are appropriate: 'At first, the procedure was optimized in respect to the extraction parameters. The optimization parameters can be found in the Additional file 1.'

\section{Sample preparation}

The frozen urine samples were completely thawed at room temperature and gently homogenized. On the basis of the above-described results, $10 \mathrm{ml}$ of each urine sample were transferred into a $20 \mathrm{ml}$ headspace vials from Labsolute (Th. Geyer, Renningen, Germany) and $2 \mathrm{~g}$ of $\mathrm{NaCl}$ were added, resulting in a concentration of $0.2 \mathrm{~g} / \mathrm{ml}$. With continuous stirring with a PTFE-coated $11 \mathrm{~mm}$ magnetic stirrer (VWR International, Darmstadt, Germany), the $\mathrm{NaCl}$ was completely dissolved and then the $\mathrm{pH}$ was adjusted to $\mathrm{pH} 2$ using $25 \% \mathrm{HCl}$. The $\mathrm{HCl}$ was added using a $10 \mu \mathrm{l}$ microliter syringe (Hamilton, Bonaduz, Swiss) while simultaneously monitoring the $\mathrm{pH}$ by means of the $\mathrm{pH}$ meter sension1 (HachLange, Berlin, Germany). Subsequently, the headspace vials were sealed with the magnetic screw caps (Th. Geyer, Renningen, Germany) and placed in the fully automatic PAL-xt sampler (Chromtech, Idstein, Germany).

\section{Separation of urinary VOM}

The VOM were extracted among continuous stirring for $30 \mathrm{~min}$ at $50{ }^{\circ} \mathrm{C}$. The enriched components were desorbed from the SPME fiber in the SSL injector for $6 \mathrm{~min}$ at $250{ }^{\circ} \mathrm{C}$. The application of the sample to the GC column was applied in splitless mode. Between each separate analysis, the SPME fiber was purified and conditioned at $290{ }^{\circ} \mathrm{C}$ for $10 \mathrm{~min}$ in a stream of nitrogen. The desorbed analytes from the SPME fiber were first separated by a GC 7890a on a fused silica DB-SELECT $624 \mathrm{UI}$ capillary column $(60 \mathrm{~m} \times 0.25 \mathrm{~mm} \times$ $1.4 \mu \mathrm{m})$ and then detected by means of a mass spectrometric detector 5975c (column and GC/MS from Agilent, Santa Clara, CA, USA). Helium was used as the carrier gas at a constant gas flow of $2 \mathrm{ml} / \mathrm{min}$. The oven program was as following: $0.3 \mathrm{~min}$ at $30{ }^{\circ} \mathrm{C}$; then rise at $10{ }^{\circ} \mathrm{C} / \mathrm{min}$ to $100{ }^{\circ} \mathrm{C}$; after rise at $3{ }^{\circ} \mathrm{C} / \mathrm{min}$ to $130{ }^{\circ} \mathrm{C}$; then rise at $5{ }^{\circ} \mathrm{C} / \mathrm{min}$ to $240{ }^{\circ} \mathrm{C}$; hold for $10.2 \mathrm{~min}$ at final temperature.

\section{Evaluation of the chromatograms}

Due to the extent of detected VOMs from the urine samples as well as to the partially unknown components and non-available standard substances a special calibration with the corresponding quantification was omitted. By the help of the ChemStation software version F.01.01.2317 (Agilent, Santa Clara, CA, USA) the evaluation were carried out semiquantitatively by the integrated peak areas. The separated peaks from the chromatograms of the 135 investigated subjects were incorporate into a separate database by means of their retention times and the specific mass-to-charge ratio $(\mathrm{m} / \mathrm{z})$ from the ion spectrum via the individual target and qualification ions. Only analytes were included in the further investigations, identified by the NIST 08 spectra library with at least $80 \%$ accuracy. 
Table 2 List of the identified VOM using the NIST 08 spectra library

\begin{tabular}{|c|c|c|c|c|c|c|c|}
\hline & \multirow[t]{2}{*}{ Name of the volatile organic metabolite (VOM) } & \multirow{2}{*}{$\begin{array}{l}\text { CAS- } \\
\text { number }\end{array}$} & \multirow{2}{*}{$\begin{array}{l}\text { Chemical } \\
\text { formula }\end{array}$} & \multirow{2}{*}{$\begin{array}{l}t_{R} \\
{[\text { mins }]}\end{array}$} & \multirow{2}{*}{$\begin{array}{l}\mathrm{m} / \\
\mathrm{z}\end{array}$} & \multicolumn{2}{|c|}{ frequency [\%] } \\
\hline & & & & & & $\overline{\mathrm{HNSCC}}$ & Healthy \\
\hline 1 & Furan & $110-00-9$ & $\mathrm{C}_{4} \mathrm{H}_{4} \mathrm{O}$ & 5.53 & 68 & 100 & 100 \\
\hline 2 & Propanal & $123-38-6$ & $\mathrm{C}_{3} \mathrm{H}_{6} \mathrm{O}$ & 5.65 & 58 & 100 & 100 \\
\hline 3 & Acetone & $67-64-1$ & $\mathrm{C}_{3} \mathrm{H}_{6} \mathrm{O}$ & 5.90 & 43 & 100 & 100 \\
\hline 4 & 3-Pentanol & $584-02-1$ & $\mathrm{C}_{5} \mathrm{H}_{12} \mathrm{O}$ & 5.97 & 59 & 100 & 92.7 \\
\hline 5 & 1-Propanol & $71-23-8$ & $\mathrm{C}_{3} \mathrm{H}_{8} \mathrm{O}$ & 7.21 & 31 & 98.1 & 93.9 \\
\hline 6 & 2-Methylfuran & $534-22-5$ & $\mathrm{C}_{5} \mathrm{H}_{6} \mathrm{O}$ & 7.46 & 82 & 100 & 100 \\
\hline 7 & 3-Methylfuran & $930-27-8$ & $\mathrm{C}_{5} \mathrm{H}_{6} \mathrm{O}$ & 7.74 & 82 & 100 & 100 \\
\hline 8 & 2-Butanone & $78-93-3$ & $\mathrm{C}_{4} \mathrm{H}_{8} \mathrm{O}$ & 7.84 & 43 & 100 & 100 \\
\hline 9 & 2-Methylbut-3-en-2-ol & $115-18-4$ & $\mathrm{C}_{5} \mathrm{H}_{10} \mathrm{O}$ & 8.24 & 71 & 100 & 100 \\
\hline 10 & Acetic acid & 64-19-7 & $\mathrm{C}_{2} \mathrm{H}_{4} \mathrm{O}_{2}$ & 8.69 & 43 & 100 & 100 \\
\hline 11 & Benzene & $71-43-2$ & $\mathrm{C}_{6} \mathrm{H}_{6}$ & 9.00 & 78 & 100 & 100 \\
\hline 12 & 3-Methylbutanal & $590-86-3$ & $\mathrm{C}_{5} \mathrm{H}_{10} \mathrm{O}$ & 9.16 & 44 & 98.1 & 100 \\
\hline 13 & Thiophene & $110-02-1$ & $\mathrm{C}_{4} \mathrm{H}_{4} \mathrm{~S}$ & 9.20 & 84 & 98.1 & 97.6 \\
\hline 14 & 2-Methylbutanal & $96-17-3$ & $\mathrm{C}_{5} \mathrm{H}_{10} \mathrm{O}$ & 9.37 & 41 & 100 & 100 \\
\hline 15 & 2-Ethylfuran & $3208-16-0$ & $\mathrm{C}_{6} \mathrm{H}_{8} \mathrm{O}$ & 9.64 & 81 & 100 & 100 \\
\hline 16 & 2,5-Dimethylfuran & $625-86-5$ & $\mathrm{C}_{6} \mathrm{H}_{8} \mathrm{O}$ & 9.84 & 96 & 100 & 100 \\
\hline 17 & 2-Pentanone & $107-87-9$ & $\mathrm{C}_{5} \mathrm{H}_{10} \mathrm{O}$ & 10.04 & 43 & 100 & 100 \\
\hline 18 & 2,4-Dimethylfuran & $3710-43-8$ & $\mathrm{C}_{6} \mathrm{H}_{8} \mathrm{O}$ & 10.15 & 96 & 98.1 & 100 \\
\hline 19 & Methyl methacrylate & $80-62-6$ & $\mathrm{C}_{5} \mathrm{H}_{8} \mathrm{O}_{2}$ & 10.23 & 55 & 100 & 100 \\
\hline 20 & 2-Ethenylfuran & 1487-18-9 & $\mathrm{C}_{6} \mathrm{H}_{6} \mathrm{O}$ & 10.65 & 105 & 100 & 100 \\
\hline 21 & Tetrahydro-2,2,5,5-tetramethylfuran & $15,045-43-9$ & $\mathrm{C}_{8} \mathrm{H}_{16} \mathrm{O}$ & 11.48 & 43 & 100 & 100 \\
\hline 22 & Dimethyl disulfide & $624-92-0$ & $\mathrm{C}_{2} \mathrm{H}_{6} \mathrm{~S}_{2}$ & 11.56 & 94 & 100 & 100 \\
\hline 23 & 3-Methyl-2-pentanone & $565-61-7$ & $\mathrm{C}_{6} \mathrm{H}_{12} \mathrm{O}$ & 11.99 & 43 & 100 & 100 \\
\hline 24 & Toluene & $108-88-3$ & $\mathrm{C}_{7} \mathrm{H}_{8}$ & 12.01 & 91 & 100 & 100 \\
\hline 25 & 2-Methylthiophene & $554-14-3$ & $\mathrm{C}_{5} \mathrm{H}_{6} \mathrm{~S}$ & 12.23 & 97 & 100 & 98.8 \\
\hline 26 & 2-Ethyl-5-methylfuran & $1703-52-2$ & $\mathrm{C}_{7} \mathrm{H}_{10} \mathrm{O}$ & 12.53 & 95 & 100 & 100 \\
\hline 27 & 3-Hexanone & 589-38-8 & $\mathrm{C}_{6} \mathrm{H}_{12} \mathrm{O}$ & 12.93 & 43 & 100 & 100 \\
\hline 28 & 2,3,5-Trimethylfuran & $10,504-04-8$ & $\mathrm{C}_{7} \mathrm{H}_{10} \mathrm{O}$ & 13.12 & 43 & 100 & 100 \\
\hline 29 & 2-Hexanone & $591-78-6$ & $\mathrm{C}_{6} \mathrm{H}_{12} \mathrm{O}$ & 13.20 & 43 & 100 & 100 \\
\hline 30 & Hexanal & $66-25-1$ & $\mathrm{C}_{6} \mathrm{H}_{12} \mathrm{O}$ & 13.47 & 44 & 100 & 100 \\
\hline 31 & m-Cresol & $108-39-4$ & $\mathrm{C}_{7} \mathrm{H}_{8} \mathrm{O}$ & 14.01 & 108 & 100 & 100 \\
\hline 32 & 2-Acetyl-5-methylfuran & 1193-79-9 & $\mathrm{C}_{7} \mathrm{H}_{8} \mathrm{O}_{2}$ & 14.31 & 109 & 100 & 100 \\
\hline 33 & 5-Methyl-3-hexanone & $623-56-3$ & $\mathrm{C}_{7} \mathrm{H}_{14} \mathrm{O}$ & 14.71 & 57 & 100 & 100 \\
\hline 34 & 4-Methyl-3-hexanone & $17,042-16-9$ & $\mathrm{C}_{7} \mathrm{H}_{14} \mathrm{O}$ & 14.94 & 57 & 100 & 100 \\
\hline 35 & Ethylbenzene & $100-41-4$ & $\mathrm{C}_{8} \mathrm{H}_{10}$ & 15.38 & 91 & 100 & 100 \\
\hline 36 & 2-Hexenal & $6728-26-3$ & $\mathrm{C}_{6} \mathrm{H}_{10} \mathrm{O}$ & 15.90 & 41 & 100 & 100 \\
\hline 37 & 4-Heptanone & 123-19-3 & $\mathrm{C}_{7} \mathrm{H}_{14} \mathrm{O}$ & 16.19 & 43 & 100 & 100 \\
\hline 38 & 2-Methylbutanoic acid & $116-53-0$ & $\mathrm{C}_{5} \mathrm{H}_{10} \mathrm{O}_{2}$ & 16.41 & 74 & 100 & 100 \\
\hline 39 & 3-Heptanone & $106-35-4$ & $\mathrm{C}_{7} \mathrm{H}_{14} \mathrm{O}$ & 14.74 & 57 & 100 & 100 \\
\hline 40 & Styrene & $100-42-5$ & $\mathrm{C}_{8} \mathrm{H}_{8}$ & 16.85 & 104 & 100 & 100 \\
\hline 41 & 2-Heptanone & $110-43-0$ & $\mathrm{C}_{7} \mathrm{H}_{14} \mathrm{O}$ & 17.05 & 43 & 100 & 100 \\
\hline 42 & Heptanal & $111-71-7$ & $\mathrm{C}_{7} \mathrm{H}_{14} \mathrm{O}$ & 17.43 & 70 & 100 & 98.8 \\
\hline 43 & 4-Methyl-2-heptanone & $6137-06-0$ & $\mathrm{C}_{8} \mathrm{H}_{16} \mathrm{O}$ & 19.00 & 43 & 100 & 100 \\
\hline
\end{tabular}


Table 2 List of the identified VOM using the NIST 08 spectra library (Continued)

\begin{tabular}{|c|c|c|c|c|c|c|c|}
\hline & \multirow[t]{2}{*}{ Name of the volatile organic metabolite (VOM) } & \multirow{2}{*}{$\begin{array}{l}\text { CAS- } \\
\text { number }\end{array}$} & \multirow{2}{*}{$\begin{array}{l}\text { Chemical } \\
\text { formula }\end{array}$} & \multirow{2}{*}{$\begin{array}{l}t_{R} \\
\text { [mins] }\end{array}$} & \multirow{2}{*}{$\begin{array}{l}\mathrm{m} / \\
\mathrm{z}\end{array}$} & \multicolumn{2}{|c|}{ frequency [\%] } \\
\hline & & & & & & HNSCC & Healthy \\
\hline 44 & 3-Methyl-2-heptanone & $2371-19-9$ & $\mathrm{C}_{8} \mathrm{H}_{16} \mathrm{O}$ & 19.25 & 43 & 100 & 100 \\
\hline 45 & 2-Ethenyltetrahydro-2,6,6-trimethyl-(2H)-pyran & $7392-19-0$ & $\mathrm{C}_{10} \mathrm{H}_{18} \mathrm{O}$ & 19.45 & 139 & 100 & 100 \\
\hline 46 & 2-Methyl-5-(methylthio)-furan & $13,678-59-6$ & $\mathrm{C}_{6} \mathrm{H}_{8} \mathrm{OS}$ & 20.19 & 128 & 100 & 100 \\
\hline 47 & Dimethyl trisulfide & $3658-80-8$ & $\mathrm{C}_{2} \mathrm{H}_{6} \mathrm{~S}_{3}$ & 20.61 & 126 & 100 & 100 \\
\hline 48 & Benzaldehyde & $100-52-7$ & $\mathrm{C}_{7} \mathrm{H}_{6} \mathrm{O}$ & 20.95 & 77 & 100 & 100 \\
\hline 49 & Terpinolen & $586-62-9$ & $\mathrm{C}_{10} \mathrm{H}_{16}$ & 21.35 & 93 & 98.1 & 100 \\
\hline 50 & 1,4-Cineole & $470-67-7$ & $\mathrm{C}_{10} \mathrm{H}_{18} \mathrm{O}$ & 21.42 & 43 & 100 & 100 \\
\hline 51 & Octanal & $124-13-0$ & $\mathrm{C}_{8} \mathrm{H}_{16} \mathrm{O}$ & 21.61 & 43 & 100 & 100 \\
\hline 52 & D-Limonene & $5989-27-5$ & $\mathrm{C}_{10} \mathrm{H}_{16}$ & 21.79 & 68 & 98.1 & 100 \\
\hline 53 & o-Cymol & $527-84-4$ & $\mathrm{C}_{10} \mathrm{H}_{14}$ & 21.93 & 119 & 100 & 100 \\
\hline 54 & 1,3,5-Trimethylbenzene & $108-67-8$ & $\mathrm{C}_{9} \mathrm{H}_{12}$ & 22.21 & 105 & 100 & 100 \\
\hline 55 & Dihydro-5-methyl-2(3H)-furanone & $108-29-2$ & $\mathrm{C}_{5} \mathrm{H}_{8} \mathrm{O}_{2}$ & 22.29 & 56 & 98.1 & 98.8 \\
\hline 56 & 1,8-Cineole & $470-82-6$ & $\mathrm{C}_{10} \mathrm{H}_{18} \mathrm{O}$ & 22.34 & 43 & 100 & 100 \\
\hline 57 & Tetrahydro-2,2-dimethyl-5-(1-methyl-1-propenyl)furan & $7416-35-5$ & $\mathrm{C}_{10} \mathrm{H}_{18} \mathrm{O}$ & 22.60 & 43 & 100 & 100 \\
\hline 58 & Phenol & $108-95-2$ & $\mathrm{C}_{6} \mathrm{H}_{6} \mathrm{O}$ & 23.42 & 94 & 100 & 100 \\
\hline 59 & 2,6-Dimethyl-7-octen-2-ol & $18,479-58-8$ & $\mathrm{C}_{10} \mathrm{H}_{20} \mathrm{O}$ & 24.13 & 59 & 100 & 100 \\
\hline 60 & Benzyl alcohol & $100-51-6$ & $\mathrm{C}_{7} \mathrm{H}_{8} \mathrm{O}$ & 24.50 & 108 & 100 & 100 \\
\hline 61 & Dehydro-p-cymol & $1195-32-0$ & $\mathrm{C}_{10} \mathrm{H}_{12}$ & 24.63 & 117 & 100 & 100 \\
\hline 62 & Tetrahydrolinalool & $78-69-3$ & $\mathrm{C}_{10} \mathrm{H}_{22} \mathrm{O}$ & 25.06 & 73 & 92.5 & 96.3 \\
\hline 63 & Linalool & $78-70-6$ & $\mathrm{C}_{10} \mathrm{H}_{18} \mathrm{O}$ & 25.30 & 71 & 100 & 100 \\
\hline 64 & Nonanal & $124-19-6$ & $\mathrm{C}_{9} \mathrm{H}_{18} \mathrm{O}$ & 25.45 & 57 & 100 & 100 \\
\hline 65 & 3,4-Dimethyl-2,5-furandione & $766-39-2$ & $\mathrm{C}_{6} \mathrm{H}_{6} \mathrm{O}_{3}$ & 25.70 & 39 & 100 & 100 \\
\hline 66 & 4-Tolualdehyde & $104-87-0$ & $\mathrm{C}_{8} \mathrm{H}_{8} \mathrm{O}$ & 25.81 & 91 & 100 & 100 \\
\hline 67 & p-Cresol & $106-44-5$ & $\mathrm{C}_{7} \mathrm{H}_{8} \mathrm{O}$ & 26.63 & 107 & 100 & 100 \\
\hline 68 & \pm-4 -Acetyl-1-methylcyclohexene & $70,286-20-3$ & $\mathrm{C}_{9} \mathrm{H}_{14} \mathrm{O}$ & 27.13 & 43 & 100 & 100 \\
\hline 69 & 1-(1,4-dimethyl-3-cyclohexen-1-yl)-ethanone & $43,219-68-7$ & $\mathrm{C}_{10} \mathrm{H}_{16} \mathrm{O}$ & 27.74 & 109 & 98.1 & 100 \\
\hline 70 & Camphor & $76-22-2$ & $\mathrm{C}_{10} \mathrm{H}_{16} \mathrm{O}$ & 28.20 & 95 & 100 & 97.6 \\
\hline 71 & 4-Terpineol & $562-74-3$ & $\mathrm{C}_{10} \mathrm{H}_{18} \mathrm{O}$ & 28.43 & 71 & 98.1 & 100 \\
\hline 72 & a-Terpineol & $98-55-5$ & $\mathrm{C}_{10} \mathrm{H}_{18} \mathrm{O}$ & 29.07 & 59 & 100 & 100 \\
\hline 73 & 1,3-Di-tert-butyl-benzene & $1014-60-4$ & $\mathrm{C}_{14} \mathrm{H}_{22}$ & 29.80 & 175 & 100 & 100 \\
\hline 74 & DL-Carvone & $99-49-0$ & $\mathrm{C}_{10} \mathrm{H}_{14} \mathrm{O}$ & 31.16 & 82 & 100 & 100 \\
\hline 75 & 4-tert-Butyl-2-chlorophenol & $98-28-2$ & $\mathrm{C}_{10} \mathrm{H}_{13} \mathrm{ClO}$ & 33.49 & 169 & 100 & 100 \\
\hline 76 & 4-tert-Butylphenol & $98-54-4$ & $\mathrm{C}_{10} \mathrm{H}_{14} \mathrm{O}$ & 33.57 & 135 & 100 & 100 \\
\hline 77 & 1,2-Dihydro-1,1,6-trimethylnaphthalene & $30,364-38-6$ & $\mathrm{C}_{13} \mathrm{H}_{16}$ & 33.82 & 157 & 100 & 100 \\
\hline 78 & $\beta$-Damascenone & $23,726-93-4$ & $\mathrm{C}_{13} \mathrm{H}_{18} \mathrm{O}$ & 35.03 & 69 & 100 & 100 \\
\hline 79 & 7,8-Dihydro-a-ionone & $31,499-72-6$ & $\mathrm{C}_{13} \mathrm{H}_{22} \mathrm{O}$ & 36.00 & 136 & 96.2 & 100 \\
\hline 80 & 3,4-Dehydro- $\beta$-ionone & $1203-08-3$ & $\mathrm{C}_{13} \mathrm{H}_{18} \mathrm{O}$ & 36.77 & 43 & 100 & 100 \\
\hline 81 & a-Calacorene & $21,391-99-1$ & $\mathrm{C}_{15} \mathrm{H}_{20}$ & 38.86 & 157 & 100 & 100 \\
\hline
\end{tabular}

\section{Statistics}

The statistical analysis and representation of the results has been done using Microsoft Office Excel $^{\circledR} 2010$ (Microsoft Deutschland $\mathrm{GmbH}$, Unterschleißheim, Germany), SPSS 20 (IBM Corporation, Armonk, NY,
USA), and STATISTICA 10 (StatSoft Inc. 2011, Tulsa, OK, USA).

For standardization, the peak areas of the identified substances were related to the respective mean value of the individual variables. To examine the distribution and 


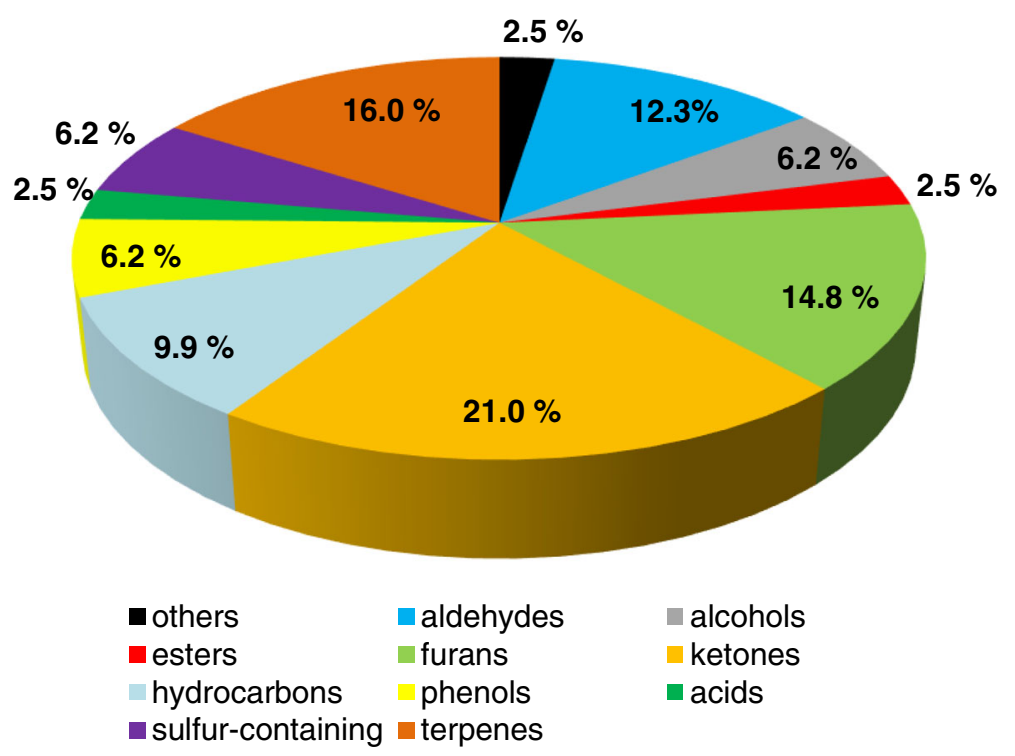

Fig. 1 Relative distribution of the VOMs according to the chemical classes

significant differences the Kolmogorow-Smirnow-test $(K S$-test) and the Student's $t$-test ( $t$-test) were used. For the recognition of patterns in the sophisticated data structure, the hierarchical cluster analysis according to the Ward-method was applied. In this context as the distance measure the Euclidean distance was used.

In addition, the multivariate procedure of the partial least squares-discriminant analysis (PLS-DA) was applied to the data set of the VOM based on the nonlinear iterative partial least squares (NIPALS) algorithm.

For all statistical calculations, a significance level of $\alpha<0.05$ was established.

\section{Results}

A total of 306 differentiated peaks from the chromatograms of the 135 measured urine samples were recorded with the use of the ChemStation ${ }^{\circ}$ software. After differentiating with the peaks assigned to the blank measurements approximately one-third of the original 306 detected peaks disappeared. As a further criterion, an equal to or greater $80 \%$ hit probability by the National Institute of Standards and Technology (NIST) 08 spectra library were determined for the identification of an unknown metabolite. Furthermore, the respective metabolite both in the control group and in HNSCC-patients

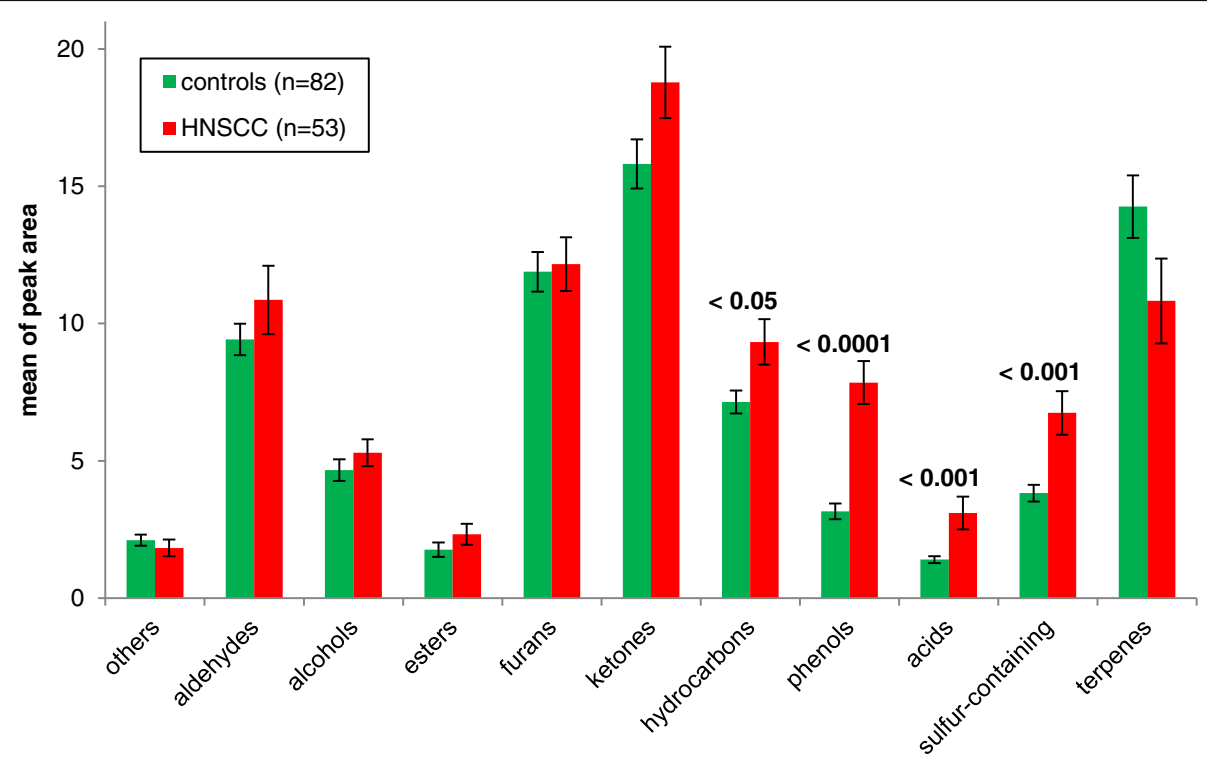

Fig. 2 Differences in the metabolite patterns relative to the chemical classes in the urine of HNSCC-patients $(n=53)$ and controls $(n=82)$ 


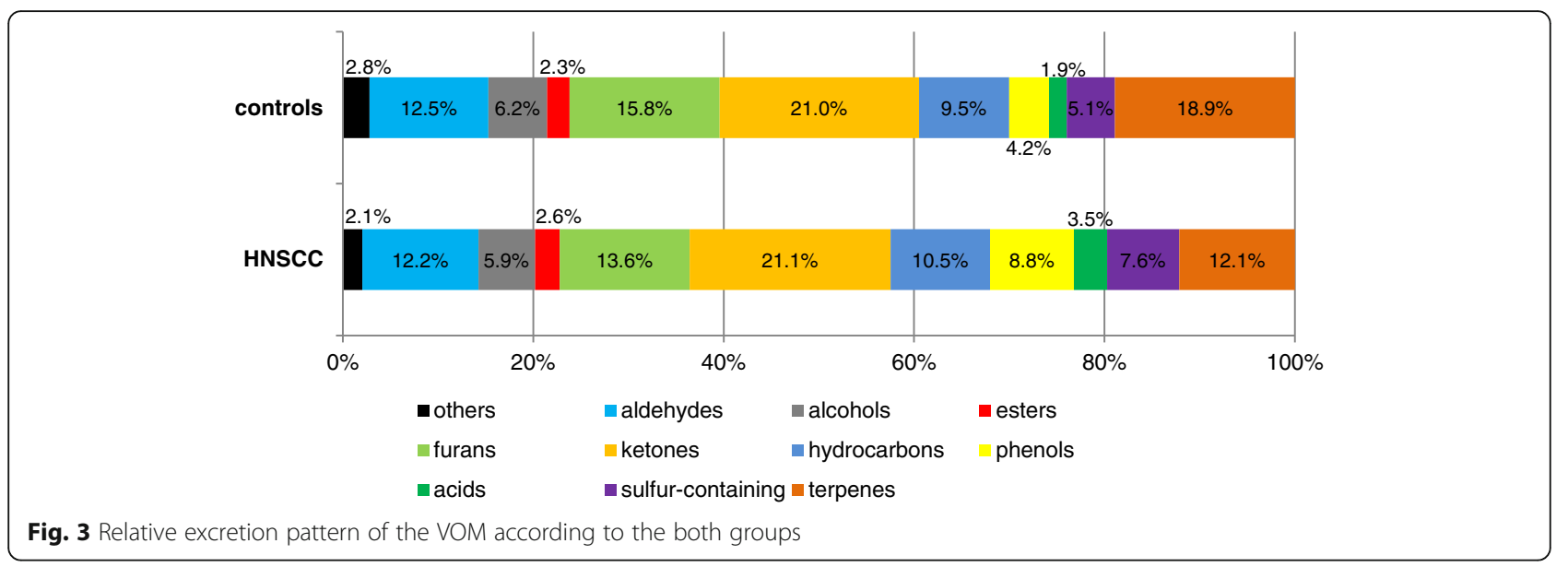

should not be below a frequency of at least $90 \%$. This finally resulted in a database of $81 \mathrm{VOM}$, which are summarized in the following Table 2.

The VOMs were classified according to their corresponding chemical classes and the relative distributions, illustrated in Fig. 1. The 81 identified VOMs included the 10 groups of aldehydes, alcohols, esters, furans, ketones, hydrocarbons, phenols, acids, sulfur-containing compounds, and terpenes. For a better overview, a separate classification into the aliphatic and aromatic hydrocarbons was omitted. The largest portion of the class of substances excreted in urine was ketones $(21.0 \%)$, followed by terpenes $(16.0 \%)$ and furans $(14.8 \%)$. On the other hand, the esters and acids each of $2.5 \%$ make the smallest contribution of the chemical compounds in the urine. In addition, it must be stated that an undoubted classification of individual compounds is not to be carried out consistently without restriction. For example, some terpenes, such as $\alpha$-terpineol and linalool occurring as monocyclic respectively acyclic monoterpene alcohols, belong by their functional group also to the substance class of alcohols. The phenols, which have been listed as an independent group, can formally also be classified to the alcohols.

\section{Differences between controls and HNSCC-patients}

Considering the renal pattern of the VOMs, summarized in the corresponding chemical classifications of patients with a tumor disease in the head and neck region and of healthy controls, there are deviations in the concentration which are characterized by the peak areas of the analyzed compounds (Fig. 2).

In the urine of the patients, the classes of hydrocarbons, phenols, acids and sulfur-containing compounds are significantly increased compared to healthy controls. In addition, the aldehydes and ketones are enhanced in the urine of patients, even if this relationship has no significant character. At least a trend for the ketones with $p=$ 0.053 can be observed. On the other hand, an increased excretion of terpenes in the urine could be detected in the control group, although this relationship is not significant.

In addition, for a simplified visual comparison of the pattern of the emitted compounds in the urine the individual classes of chemicals were compared with the total sum of all occurring substance classes and the HNSCC-patients were plotted against the healthy study population. At becomes apparent that the increase in the proportion of furans and terpenes in the urine of the healthies against the patients, while the spectrum in patients is shifted to the phenols and sulfur-containing compounds (Fig. 3).

For the derivation of specific metabolite markers, which may indicate a tumor disease in the urine, the difference of the means between the patient and control group were plotted against each other. The green bars on the left side symbolize a higher difference in mean values in the control group, whereas the red bars represent a higher mean in the group of patients (Fig. 4). In addition, the significant differences between the two groups were distinguished based on the comparison of the mean values. The 25 VOMs m-cresol, 3-heptanone, benzene, 4-meth yl-2-heptanone, acetone, 1-propanol, nonanal, 4-tert-butylphenol, phenol, 3-methyl-2-heptanone, dimethyltrisulfide, 2-hexanone, ethanoic acid, furan, hexanal, 2-methyl-5-(methylthio) furan, heptanal, dimethyldisulfide, 2-methylthiophene, tetrahydro-2,2dimethyl-5-(1-methyl-1-propenyl)furan,

2-methylbutyric acid, styrene, 2-ethylfuran, ethylbenzene and thiophene were significantly increased in the urine of patients with malignant neoplasia.

In contrast, it can be noted that 10 VOMs were significantly reduced in the urine of HNSCC-patients compared to the healthy controls. These components included 2-ethyl-5-methylfuran, 3,4-dimethyl-2,5-furanedione, 3,4-dehydro- $\beta$-ionone, 2-methylbutanal, linalool, 1,8-cineol, 2-butanone, $\alpha$-terpineol, tetrahydro-2,2,5,5-te tramethylfuran and 2-hexenal. 


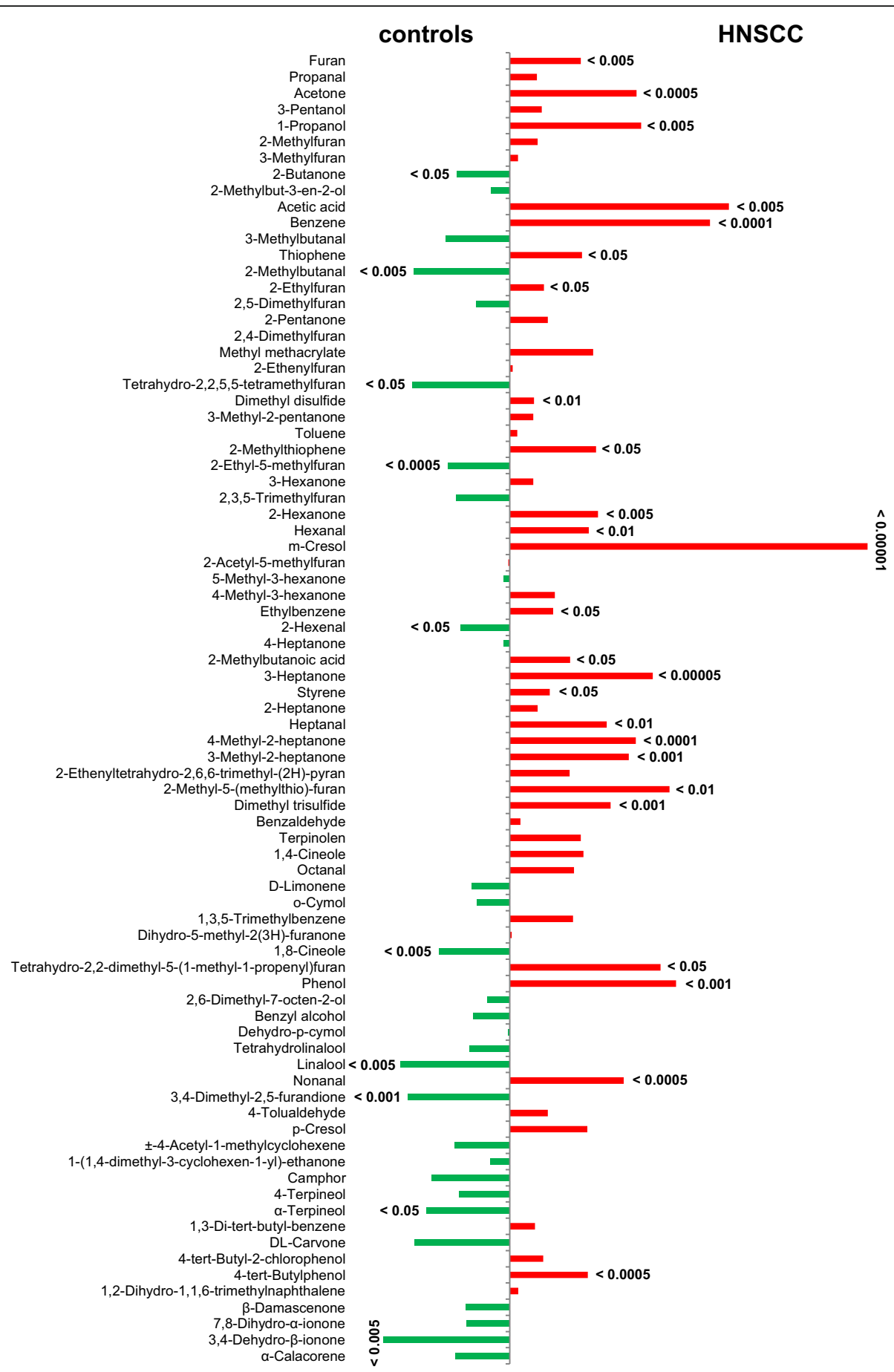

Fig. 4 Significant differences between controls (left - green) and HNSCC patients (right - red) in the VOM pattern

\section{Multivariate analyzes of VOM}

First, the standardized peak areas of the 81 captured VOMs from the urine of the study cohort as well as the target variable were incorporated for the systematic analysis. Target variable was declared as a "health state" in the dendrogram. In order to integrate all existing cases into the investigation, missing values in the data set were replaced by the corresponding mean value of the variable. Figure 5 shows the dendrogram of the cluster analysis performed, with the location of the target variable at the far right of the graph. As appears from the figure, $\mathrm{m}$-cresol has obviously the smallest distance measure towards the target variable and forms with it the smallest cluster at the very edge on the right side of the diagram. 


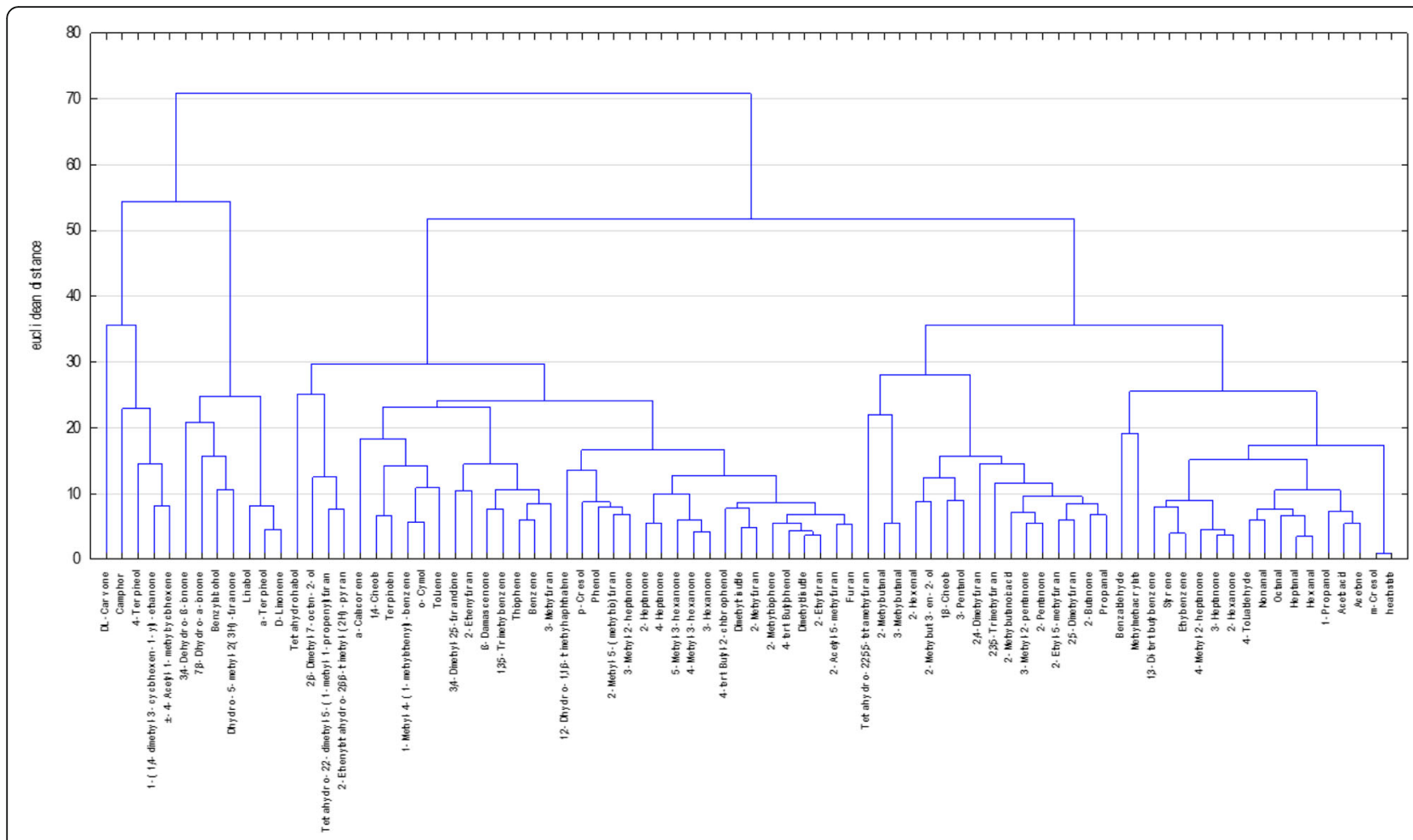

Fig. 5 Dendrogram of the 81 analyzed VOMs and the target variable "health state" (right side)

In the next step, the target variable "health state" is combined with a series of variables to the next larger cluster. In fact, this cluster is composed of two further clusters, whereby the variables acetone, ethanoic acid, 1-propanol, hexanal, heptanal, octanal, nonanal, 4-tolualdehyde are contained on the right side. In the left cluster, the variables 2-hexanone, 3-heptanone, 4-methyl-2-heptanone, ethylbenzene, styrene and 1,3-di-tert-butylbenzene are combined into a common group. The terpenes DL-carvone, camphor and 4-terpineol are located farthest from the target variable, which are found in the dendrogram shown at the extreme left margin.

Furthermore, the hierarchical cluster analysis shows that separate VOMs belonging to the same chemical class are combined to the corresponding clusters. For example, the group of aldehydes around hexanal, heptanal and octanal forms their own cluster. This is reflected in further chemical compounds, such as the alcohols, ketones and terpenes.

In the further course the 135 cases of the entire study population were subjected to the cluster analysis. In this evaluation only the statistically significant VOMs from the univariate analysis were included as variables, which are reproduced in Fig. 4. Analog to the previous cluster analysis, missing values in the data matrix were replaced by the corresponding mean values to allow that all 135 study participants were involved. The results of the subordinate hierarchical cluster analysis are shown in Fig. 6. For a simplified overview, the HNSCC-patients at the left end were marked red and the controls were marked green. From the dendrogram it can be seen that the controls and patients with a tumor disease are not generally divided into two superordinate clusters. There are areas in the middle of the tree structure where healthy people and HNSCC-patients are grouped as a cluster based on similarity structures in the pattern of the incoming variables. Despite this, there are wide areas within the dendrogram where the patients can be grouped into individual clusters due to their similarities in the VOM pattern. This effect is also characteristic for the controls, especially at the lower end of the tree structure in Fig. 6.

As another multivariate procedure for discriminating between HNSCC-patients and controls, as well as the derivation of potential tumor markers which are responsible for the separation between the two case groups, the supervised PLS-DA was applied which considered the assignment of the two groups. The state of health of the 135 study participants $(0=$ controls, $1=$ HNSCC $)$ served as a categorical, dependent variable, whereas the significant VOM from the univariate analysis were entered as steady predictors into the model. To ensure the quality of the created model a 7-fold cross-validation was carried out. 


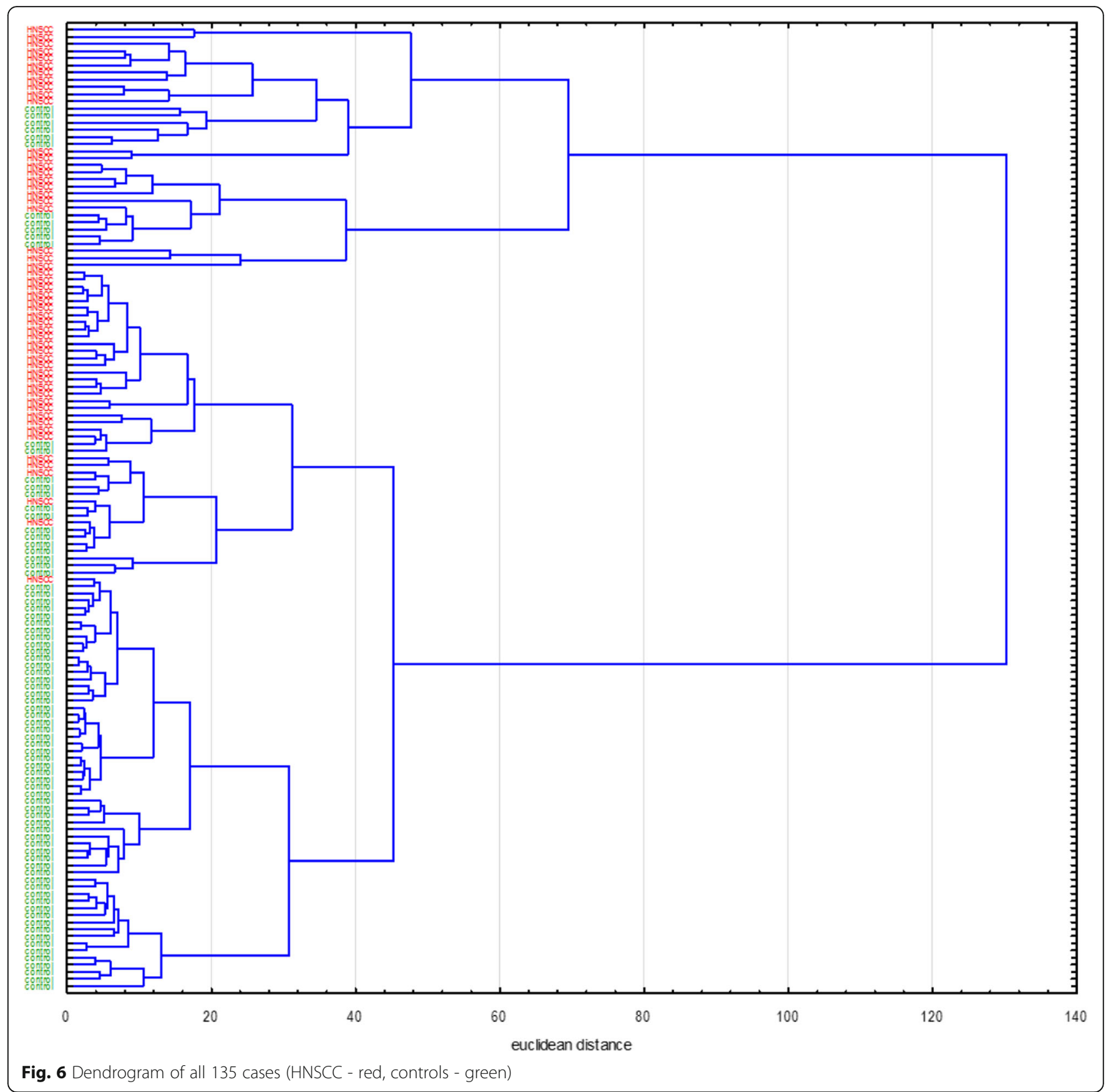

The results of the PLS-DA are illustrated in a standardized biplot (Fig. 7). This allows presenting the cases sorted by groups together with the incoming variables in a two-dimensional projection. The patients with a tumor in the head and neck region are shown as red circles in the study cohort, while the controls are characterized by blue triangles. On the other hand, the variables are described by the course of the colored axes in the standardized biplot, from which are derived the charges of the individual variables from the respective component axis $\mathrm{t} 1$ or $\mathrm{t} 2$. For example, acetone has a high charge towards component $\mathrm{t} 1$ since the variable axis is almost parallel to the corresponding component axis $t 1$. In addition, the correlation relations of the variables among each other can be determined from the variable axes. For example, a very strong correlation between 1,8-cineol and 1-propanol can be found in the biplot, which was summarized by the very close neighboring position in the legend. After a closer look at the two variables in the weight plot, which is not listed separately, a negative correlation relation is shown. The standardized biplot demonstrates that the discrimination is generally possible, taking into account the VOM pattern between the two groups, even if two of the tumor patients were wrongly classified into the control group. In addition, the HNSCC-patients show a greater spread, while the 


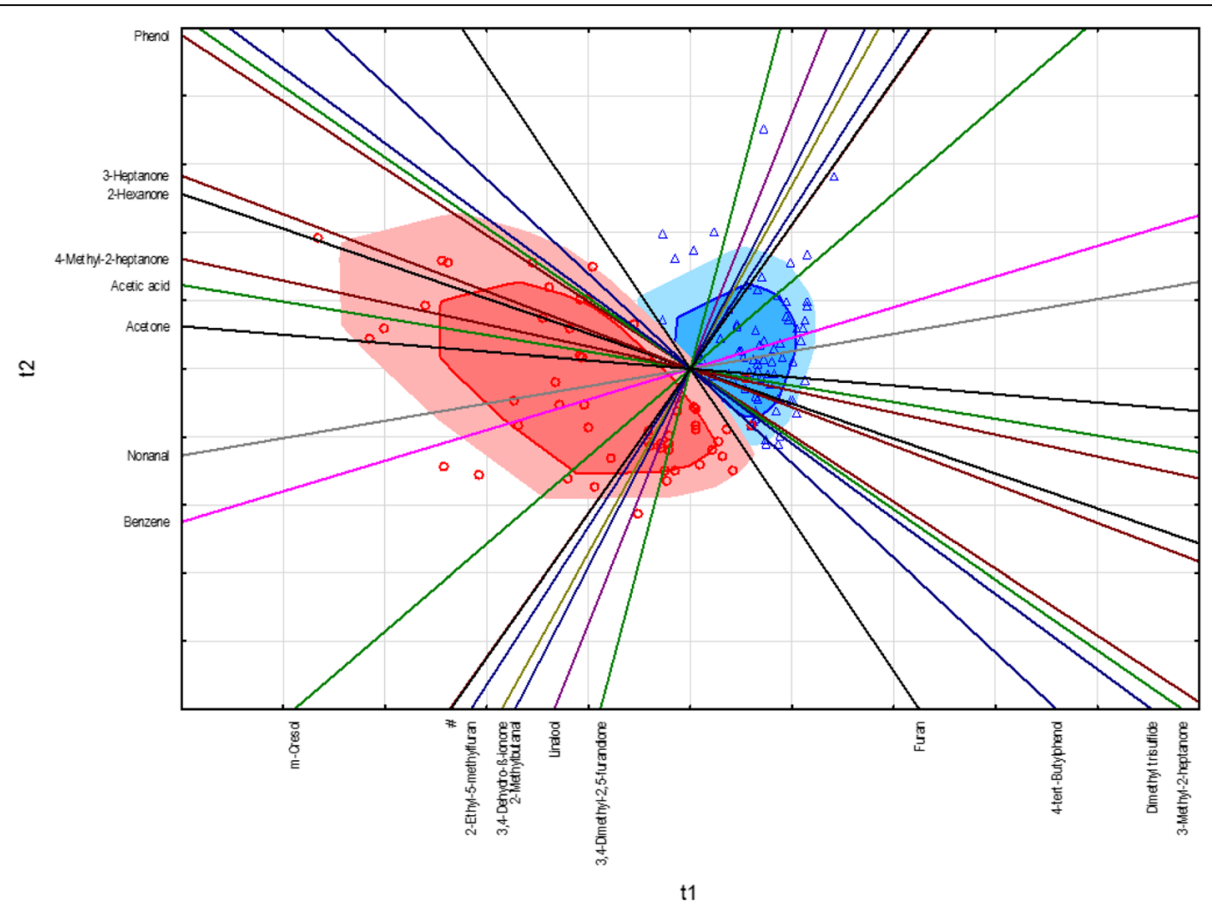

Fig. 7 Standardized biplot of the PLS-DA between HNSCC-patients (red circles) and controls (blue triangles), (\# - 1,8-cineole and 1-propanol)

controls are more homogeneous in their pattern. For the classification between the two groups, m-cresol, benzene, nonanal and acetone seem to be the most likely VOM to identify patients with malignant neoplasia in the head and neck region.

\section{Discussion}

The importance of the human VOM is being increasingly discussed to what extent these are able to reflect the current metabolic situation and accordingly the health condition $[1,2,8,34]$. So far, the focus has been laid on the detection of exhaled volatile metabolites by means of respiratory gas analyzes for the diagnosis of very different disease pictures, e.g. allergic asthma [9], chronic obstructive pulmonary disease (COPD) [6], renal dysfunction [17], liver cirrhosis [10], hepatocellular carcinoma [30], mama carcinoma [19, 27], and bronchial carcinomas [11, 28, 41]. Above all, the exhaled biomarker 2-methyl-1,3-butadiene, better known as isoprene, represents a promising target of clinical diagnostics. Isoprene is the basic unit of terpenes and is generated during the cholesterol biosynthesis in the mevalonate pathway [20]. Furthermore, the identification of specific VOM signatures is also encourage in the stool as well as other body fluids, such as, blood, sweat secretion, saliva and urine. Specifically, urine is particularly suitable for the detection of prognostic biomarkers since a large number of metabolic end products are excreted in the urine which passes through the complexity of all biochemical pathways in the human organism. Besides, using urine as sample matrix is a non-invasive procedure, thereby avoiding a superfluous physical burden or unexpected side effects due to the examination for the patient.

The results of this study demonstrated that patients with squamous cell carcinoma in the head and neck region exhibit characteristic patterns of VOMs in the urine compared to healthy subject groups. Above all, the volatile metabolites belonging to the chemical compounds of the aldehydes, ketones, hydrocarbons, phenols, acids and sulfur-containing compounds have been found increased in the urine of HNSCC-patients. On the other hand, the substance class of the terpenes showed an inverse behavior. Concretely, for the compounds m-cresol, 3-heptanone, benzene, 4-methyl-2-heptanone, acetone, 1-propanol, nonanal, 4-tert-butylphenol, phenol, 3-methyl-2-heptanone, dimethyl trisulfide, 2-methyl-5(methylthio) furan, heptanal, dimethyl disulfide, 2-methylthiophene, tetrahydro-2, 2-dimethyl-5-(1-methyl -1-propenyl) furan, 2-methyl-butyric acid, styrene, 2-ethylfuran, ethylbenzene and thiophene were determined significantly higher levels in the urine of the patient population. While the following VOMs presented significantly reduced; 2-ethyl-5-methylfuran, 3,4-dimethyl-2, 5 -furanedione, 3,4-dehydro- $\beta$-ionone, 2 -methylbutanal, linalool, 1,8-cineol, 2-butanone, $\alpha$-terpineol, tetrahydro2,2,5,5-tetramethylfuran and 2-hexenal. Furthermore, the multivariate statistics confirmed that on the basis of the 
renal excreted pattern of the volatile metabolites a classification between the two investigated study cohorts can be carried out. In addition to m-cresol and benzene, the substance group of the saturated, unbranched aldehydes shows a significant contribution. This substance class formed also a defined cluster separated from the other chemical compounds in the dendrogram due to their similarity in the renal excretion pattern (Fig. 5). In addition to the hydrocarbons ethane and pentane, which are frequently used for respiratory gas-mediated tumor diagnostics $[8,14]$, the aldehydes are also used as volatile biomarkers for the lipid peroxidation of unsaturated fatty acids $[13,31]$. Their detection is associated with the occurrence of oxidative stress which is initiated as a result of a disturbed equilibrium between free oxygen radicals and antioxidants. This is due to the overproduction of reactive oxygen species (ROS), such as the superoxide, hydrogen peroxide and the hydroxyl radical, which are produced intracellularly as byproducts of the cellular respiration in mitochondria and secreted into the cytoplasm of the cell [33]. In addition to the generation of oxidative stress, which is responsible for a number of pathological processes, including diabetes, inflammatory and neurodegenerative diseases, early aging and the initiation of carcinogenesis [29], ROS also play a central role as secondary messengers in regulatory processes within the cell, as well migration, proliferation and programmed cell death. Numerous studies have proved the intracellularly increased concentrations of ROS in tumor cell lines as well as in the microenvironment of tumors, where they promote the further tumor progression [7, 21]. Furthermore, ROS are capable of causing the oxidation of biologically central molecules such as DNA, RNA, and proteins. Besides, they initiate the lipid peroxidation of polyunsaturated omega- 3 and omega- 6 fatty acids, which serve as basic components of cell membrane lipids, whereas among others unsaturated and saturated aldehydes are formed as secondary degradation products $[12,25]$. In this context malondialdehyde, 4-hydroxynonenal, propanal and hexanal have been described as suitable markers $[4,16]$. Up to now an increased release of aldehydes were found in the exhaled air [19], blood [40] and urine [12] of patients with various tumor diseases.

On the one hand, from a scientific point of view, on the other hand, to advance an early clinical diagnosis, there is a marked interest in assigning the individual VOMs to their respective place of origin to derive any characteristic tumor markers or biomarkers which reflect an unfavorable exposure. Up to now, the development processes of the VOM have not been known very well. In general a distinction is made between endogenous and exogenous volatile metabolites. Exogenous results from ingested food, from inhaled air pollutants and microbial colonization. A following unpublished publication will following to examine the origins of the humans VOM with exogenous influences, such as alcohol consumption and tobacco smoke.

\section{Additional file}

Additional file 1: Figure S1 Effect of the extraction time on the peak area sum of all analytes at $50{ }^{\circ} \mathrm{C}$ with a CAR / PDMS fiber. Figure S2 Correlation between the extraction and addition of $\mathrm{NaCl}$, as well as the shift of the $\mathrm{pH}$ value. (DOCX $335 \mathrm{~kb})$

\section{Abbreviations \\ Cl: Confidence interval; COPD: Chronic obstructive pulmonary disease; GC: Gas chromatography head and neck (ENT) clinic; HNSCC: Head and neck squamous cell carcinoma; MS: Mass spectrometry; MVOC: Microbial volatile organic compounds; NIPALS: Nonlinear iterative partial least squares; NIST: National Institute of Standards and Technology; NN: Neuronal network; OR: Odds ratio; PCA: Principal component analysis; PLS-DA: Partial least squares - discriminant analysis; ROC: Receiver operation characteristic; ROS: Reactive oxygen species; SPME: Solid-phase micro extraction; VOC: Volatile organic compounds; VOM: Volatile organic metabolites}

\section{Funding}

We acknowledge support from the German Research Foundation (DFG) and Leipzig University within the program of Open Access Publishing. Parts of this study were funded by the Leipzig Research Center for Civilization Diseases (LIFE) (Grant numbers: LIFE-006 B7, LIFE-007 D9).

\section{Authors' contributions}

PO: data collection, data analysis, manuscript drafting. $\mathrm{OH}$ : concept \& design, manuscript editing and revision. Both authors read and approved the final manuscript.

\section{Ethics approval and consent to participate}

All procedures performed in studies involving human participants were in accordance with the ethical standards of the institutional and/or national research committee and with the 1964 Helsinki declaration and its later amendments or comparable ethical standards.

All urine samples were taken after obtaining written patient's informed consent as approved by the local institutional review board (votes of the ethics committee of the Medical Faculty of the University Leipzig No. (NUCLEO No. 201-10-12072010 \& No. 202-10-12072010)).

\section{Consent for publication}

Not Applicable.

\section{Competing interests}

The authors declare that they have no competing interest.

\section{Publisher's Note}

Springer Nature remains neutral with regard to jurisdictional claims in published maps and institutional affiliations.

\section{Author details}

${ }^{1}$ Institute of Hygiene, Hospital Hygiene and Environmental Medicine, University Hospital Leipzig, Johannisallee 34, 04103 Leipzig, Germany. ${ }^{2}$ Institute of Environmental Medicine and Hygiene, Faculty of Medicine, University of Leipzig, Liebigstr. 27, 04103 Leipzig, Germany.

Received: 20 July 2017 Accepted: 25 June 2018

Published online: 03 July 2018

\section{References}

1. Amann A, Costello BL, Miekisch W, Schubert J, Buszewski B, Pleil J, Ratcliffe N, Risby T. The human volatilome: volatile organic compounds (VOCs) in exhaled breath, skin emanations, urine, feces and saliva. J Breath Res. 2014; 8(3):34001. https://doi.org/10.1088/1752-7155/8/3/034001.

2. Arasaradnam RP, Westenbrink E, McFarlane MJ, Harbord R, Chambers S, O'Connell N, Bailey C, Nwokolo CU, Bardhan KD, Savage R, Covington JA. 
Differentiating coeliac disease from irritable bowel syndrome by urinary volatile organic compound analysis-a pilot study. PLoS One. 2014;9(10): e107312. https://doi.org/10.1371/journal.pone.0107312.

3. Arthur CL, Pawliszyn J. Solid phase microextraction with thermal desorption using fused silica optical fibers. Anal Chem. 1990;62(19):2145-8.

4. Ayala A, Munoz MF, Arguelles S. Lipid peroxidation: production, metabolism, and signaling mechanisms of malondialdehyde and 4-hydroxy-2-nonenal. Oxidative Med Cell Longev. 2014;2014:360438. https://doi.org/10.1155/2014/360438.

5. Banday KM, Pasikanti KK, Chan ECY, Singla R, Rao KVS, Chauhan VS, Nanda RK. Use of urine volatile organic compounds to discriminate tuberculosis patients from healthy subjects. Anal Chem. 2011;83(14):5526-34. https://doi. org/10.1021/ac200265g.

6. Besa V, Teschler H, Kurth I, Khan AM, Zarogoulidis P, Baumbach Jl, Sommerwerck U, Freitag L, Darwiche K. Exhaled volatile organic compounds discriminate patients with chronic obstructive pulmonary disease from healthy subjects. Int J Chron Obstruct Pulmon Dis. 2015;10:399-406. https:// doi.org/10.2147/COPD.S76212.

7. Bhattacharyya S, Saha J. Tumour, oxidative stress and host T cell response: cementing the dominance. Scand J Immunol. 2015;82(6):477-88. https://doi. org/10.1111/sji.12350.

8. Broza YY, Mochalski P, Ruzsanyi V, Amann A, Haick H. Hybrid volatolomics and disease detection. Angew Chem Int Ed Engl. 2015;54(38):11036-48. https://doi.org/10.1002/anie.201500153.

9. Dallinga JW, Robroeks CMHHT, van Berkel JJBN, Moonen EJC, Godschalk RWL, Jobsis Q, Dompeling E, Wouters EFM, van Schooten FJ. Volatile organic compounds in exhaled breath as a diagnostic tool for asthma in children. Clin Exp Allergy. 2010;40(1):68-76. https://doi.org/10.1111/j.1365-2222.2009.03343.x.

10. Fernandez Del Rio R, O'Hara ME, Holt A, Pemberton P, Shah T, Whitehouse T, Mayhew CA. Volatile biomarkers in breath associated with liver cirrhosis comparisons of pre- and post-liver transplant breath samples. EBioMedicine. 2015;2(9):1243-50. https://doi.org/10.1016/j.ebiom.2015.07.027.

11. Filipiak W, Filipiak A, Sponring A, Schmid T, Zelger B, Ager C, Klodzinska E, Denz H, Pizzini A, Lucciarini P, Jamnig H, Troppmair J, Amann A. Comparative analyses of volatile organic compounds (VOCs) from patients, tumors and transformed cell lines for the validation of lung cancer-derived breath markers. J Breath Res. 2014;8(2):27111. https://doi.org/10.1088/1752-7155/8/2/027111.

12. Guadagni R, Miraglia N, Simonelli A, Silvestre A, Lamberti M, Feola D, Acampora A, Sannolo N. Solid-phase microextraction-gas chromatographymass spectrometry method validation for the determination of endogenous substances: urinary hexanal and heptanal as lung tumor biomarkers. Anal Chim Acta. 2011;701 (1):29-36. https://doi.org/10.1016/j.aca.2011.05.035.

13. Haick H, Broza YY, Mochalski P, Ruzsanyi V, Amann A. Assessment, origin, and implementation of breath volatile cancer markers. Chem Soc Rev. 2014; 43(5):1423-49. https://doi.org/10.1039/c3cs60329f.

14. Hakim M, Broza YY, Barash O, Peled N, Phillips M, Amann A, Haick H. Volatile organic compounds of lung cancer and possible biochemical pathways. Chem Rev. 2012:112(11):5949-66. https://doi.org/10.1021/cr300174a.

15. Katsoyiannis A, Leva P, Kotzias D. VOC and carbonyl emissions from carpets: a comparative study using four types of environmental chambers. J Hazard Mater. 2008;152(2):669-76. https://doi.org/10.1016/j.jhazmat.2007.07.058.

16. Kim DH, Kwack SJ, Yoon KS, Choi JS, Lee B. 4-Hydroxynonenal: a superior oxidative biomarker compared to malondialdehyde and carbonyl content induced by carbon tetrachloride in rats. J Toxicol Environ Health A. 2015; 78(16):1051-62. https://doi.org/10.1080/15287394.2015.1067505.

17. Kohl I, Beauchamp J, Cakar-Beck F, Herbig J, Dunkl J, Tietje O, Tiefenthaler M, Boesmueller C, Wisthaler A, Breitenlechner M, Langebner S, Zabernigg A, Reinstaller F, Winkler K, Gutmann R, Hansel A. First observation of a potential non-invasive breath gas biomarker for kidney function. J Breath Res. 2013;7(1):17110. https://doi.org/10.1088/1752-7155/7/1/017110.

18. Lacy Costello B, de Amann A, Al-Kateb H, Flynn C, Filipiak W, Khalid T, Osborne $D$, Ratcliffe NM. A review of the volatiles from the healthy human body. J Breath Res. 2014;8(1):14001. https://doi.org/10.1088/1752-7155/8/1/014001.

19. Li J, Peng Y, Liu Y, Li W, Jin Y, Tang Z, Duan Y. Investigation of potential breath biomarkers for the early diagnosis of breast cancer using gas chromatography-mass spectrometry. Clin Chim Acta. 2014;436:59-67. https://doi.org/10.1016/j.cca.2014.04.030

20. Liao P, Hemmerlin A, Bach TJ, Chye M. The potential of the mevalonate pathway for enhanced isoprenoid production. Biotechnol Adv. 2016;34(5): 697-713. https://doi.org/10.1016/j.biotechadv.2016.03.005.

21. Liou G, Storz P. Reactive oxygen species in cancer. Free Radic Res. 2010; 44(5):479-96. https://doi.org/10.3109/10715761003667554.
22. Mangler M, Freitag C, Lanowska M, Staeck O, Schneider A, Speiser D. Volatile organic compounds (VOCs) in exhaled breath of patients with breast cancer in a clinical setting. Ginekol Pol. 2012;83(10):730-6.

23. Matsumura K, Opiekun M, Oka H, Vachani A, Albelda SM, Yamazaki K, Beauchamp GK. Urinary volatile compounds as biomarkers for lung cancer: a proof of principle study using odor signatures in mouse models of lung cancer. PLoS One. 2010;5(1):e8819. https://doi.org/10. 1371/journal.pone.0008819.

24. Matysik S, Herbarth O, Mueller A. Determination of volatile metabolites originating from mould growth on wall paper and synthetic media. J Microbiol Methods. 2008;75(2):182-7. https://doi.org/10.1016/.mimet.2008.05.027.

25. Miekisch W, Schubert JK, Noeldge-Schomburg GFE. Diagnostic potential of breath analysis-focus on volatile organic compounds. Clin Chim Acta. 2004; 347(1-2):25-39. https://doi.org/10.1016/j.cccn.2004.04.023.

26. Peng G, Hakim M, Broza YY, Billan S, Abdah-Bortnyak R, Kuten A, Tisch U, Haick H. Detection of lung, breast, colorectal, and prostate cancers from exhaled breath using a single array of nanosensors. Br J Cancer. 2010;103(4): 542-51. https://doi.org/10.1038/sj.bjc.6605810.

27. Phillips M, Cataneo RN, Saunders C, Hope P, Schmitt P, Wai J. Volatile biomarkers in the breath of women with breast cancer. J Breath Res. 2010; 4(2):26003. https://doi.org/10.1088/1752-7155/4/2/026003.

28. Poli D, Carbognani P, Corradi M, Goldoni M, Acampa O, Balbi B, Bianchi L, Rusca M, Mutti A. Exhaled volatile organic compounds in patients with nonsmall cell lung cancer: cross sectional and nested short-term follow-up study. Respir Res. 2005;6:71. https://doi.org/10.1186/1465-9921-6-71.

29. Prasad S, Gupta SC, Tyagi AK. Reactive oxygen species (ROS) and cancer: role of antioxidative nutraceuticals. Cancer Lett. 2017;387:95-105. https://doi. org/10.1016/j.canlet.2016.03.042.

30. Qin T, Liu H, Song Q, Song G, Wang H, Pan Y, Xiong F, Gu K, Sun G, Chen Z. The screening of volatile markers for hepatocellular carcinoma. Cancer Epidemiol Biomark Prev. 2010;19(9):2247-53. https://doi.org/10.1158/1055-9965.EPI-10-0302.

31. Repetto M, Semprine J, Boveris A. Lipid Peroxidation: Chemical Mechanism, Biological Implications and Analytical Determination, Lipid Peroxidation Angel Catala, IntechOpen. 2012. https://doi.org/10.5772/45943

32. Roine A, Veskimae E, Tuokko A, Kumpulainen P, Koskimaki J, Keinanen TA, Hakkinen MR, Vepsalainen J, Paavonen T, Lekkala J, Lehtimaki T, Tammela TL, Oksala NKJ. Detection of prostate cancer by an electronic nose: a proof of principle study. J Urol. 2014;192(1):230-4. https://doi.org/10.1016/j.juro. 2014.01.113.

33. Sena LA, Chandel NS. Physiological roles of mitochondrial reactive oxygen species. Mol Cell. 2012;48(2):158-67. https://doi.org/10.1016/..molcel.2012.09.025

34. Silva $\mathrm{CL}$, Passos M, Camara JS. Investigation of urinary volatile organic metabolites as potential cancer biomarkers by solid-phase microextraction in combination with gas chromatography-mass spectrometry. Br J Cancer. 2011;105(12):1894-904. https://doi.org/10. 1038/bjc.2011.437.

35. Wang C, Sun B, Guo L, Wang X, Ke C, Liu S, Zhao W, Luo S, Guo Z, Zhang Y, $X u$ G, Li E. Volatile organic metabolites identify patients with breast cancer, cyclomastopathy, and mammary gland fibroma. Sci Rep. 2014;4:5383. https://doi.org/10.1038/srep05383.

36. Weber CM, Cauchi M, Patel M, Bessant C, Turner C, Britton LE, Willis CM. Evaluation of a gas sensor array and pattern recognition for the identification of bladder cancer from urine headspace. Analyst. 2011;136(2): 359-64. https://doi.org/10.1039/c0an00382d.

37. Willmann L, Erbes T, Krieger S, Trafkowski J, Rodamer M, Kammerer B. Metabolome analysis via comprehensive two-dimensional liquid chromatography: identification of modified nucleosides from RNA metabolism. Anal Bioanal Chem. 2015;407(13):3555-66. https://doi.org/10. 1007/s00216-015-8516-6

38. World Health Organization. Indoor air quality: organic pollutants. Euro reports and studies, vol. 111. Copenhagen: World Health Organization; 1989.

39. World Health Organization. Air quality guidelines for Europe, 2nd ed. WHO regional publications. European series, no. 91. Copenhagen: World Health Organization, Regional Office for Europe; 2000.

40. Xue R, Dong L, Zhang S, Deng C, Liu T, Wang J, Shen X. Investigation of volatile biomarkers in liver cancer blood using solid-phase microextraction and gas chromatography/mass spectrometry. Rapid Commun Mass Spectrom. 2008;22(8):1181-6. https:/doi.org/10.1002/rcm.3466.

41. Zou Y, Zhang X, Chen X, Hu Y, Ying K, Wang P. Optimization of volatile markers of lung cancer to exclude interferences of non-malignant disease. Cancer Biomark. 2014;14(5):371-9. https://doi.org/10.3233/CBM-140418. 